\title{
ARTYKULY
}

Beata Spieralska

Warszawa

\section{O średniowiecznym kompilatorstwie i transmisji tekstu na przykładzie Kroniki Benedykta, mnicha z klasztoru św. Andrzeja}

Do źródeł historiograficznych z X-wiecznej Italii należy tak zwana Kronika Benedykta, mnicha z klasztoru św. Andrzeja na górze Soracte w Lacjum. Autorstwo Kroniki przypisuje się mnichowi Benedyktowi na podstawie jednej tylko wzmianki. Na karcie 40 recto manuskryptu przytoczone są bowiem wersy, które na cześć Karola Wielkiego napisał Gerwardus ${ }^{1}, \mathrm{z}$ tym że zamiast „Gerwardus supplex famulus” („Gerward, pokorny sługa”) mamy tam: „Benedictus supplex famulus monachus” („Benedykt pokorny sługa, mnich”); przy okazji należy zaznaczyć, że zamiany tej dokonano z całkowitym lekceważeniem zasad metrycznych. Ponad powyższe, na temat owego Benedykta nie wiemy absolutnie nic. Przypisanie mu autorstwa Kroniki ma więc raczej funkcję „etykietki” niż odwołania do konkretnej osoby. Jeżeli więc w dalszej części niniejszych rozważań będę nazywała autora omawianej kroniki imieniem „Benedykt”, to z pełną świadomością umowności tej identyfikacji.

Pierwszy wydawca Kroniki, G. Pertz, zaproponował, by za miejsce jej powstania uznać klasztor św. Andrzeja na górze Soracte. I znów mamy tu do czynienia z hipotezą o bardzo wątłych podstawach źródłowych, albowiem o klasztorze tym znajdujemy w Kronice tylko jedną wzmiankę. W rękopisie czytamy: „simul cum ipso pontifice usque ad montes Syrapti, ad monasterium sancti Siluestri deuenit. Deinde ad monasterium

${ }^{1}$ Hos tibi versiculos ad laudem, maxime princeps / Edidit aeternam memoriamque tuam / Gerwardus supplex famulus, qui mente benigna... Wersy te znamy z niektórych rękopisów $\dot{Z} y$ wota Karola Wielkiego Einharda - por. Einhardi Vita Varoli Magni, post G. H. Pertz recensuit G. Wais, editio sexta, curavit O. Holder-Egger, Hannoverae-Lipsiade 1911, s. XXIX. 
sancti Andreae cum pontifice summo adest qui rogatus imperator a[d] pontifice ut aliquantulum reliquiarum de corpore sancti Andreae apostoli in hunc monasterium consecrationis < causa > constitueret. Cuius loco positus est in hunc monasterium uenerabile ecclesiae, apud nos incognitum est"'. Autor Kroniki opowiada zatem, jak to Karol Wielki, wracając z Konstantynopola, ,wraz z tymże papieżem aż do góry Soracte, do klasztoru św. Sylwestra przybył. Następnie do klasztoru świętego Andrzeja z papieżem dotarł i poproszony został cesarz przez papieża, żeby odrobinę z relikwii z ciała świętego Andrzeja apostoła w tym klasztorze, celem jego konsekracji przekazał". Pomimo wadliwej składni ostatniego zdania, można bez większego trudu zrozumieć, że autor nie wie, gdzie w klasztorze zostały złożone relikwie. Co do samej góry Soracte (w różnych wariantach graficznych) oraz znajdującego się na niej kościoła św. Sylwestra, to są one w Kronice wymieniane dość często. Pierwszą wzmiankę o nich znajdujemy na karcie $1 \mathrm{v}$.

Kronika Benedykta zachowała się w jednym tylko rękopisie ${ }^{3}$ datowanym na przełom wieków X i XI. Kodeks należał do kolekcji Palazzo Chigi, a obecnie znajduje się w Bibliotece Watykańskiej (Chig.F.IV.75). Uszkodzenie, jakiemu uległ kodeks (zawierający oprócz Kroniki również fragment 33. rozdziału Żywota Karola Wielkiego Einharda, zwanego Testamentum Caroli oraz wyciąg z kapitularza karolińskiego), nie pozwala stwierdzić, od jakiego momentu autor kroniki rozpoczął swą relację historyczną, ani w jakim dokładnie momencie ją skończył. Zachowana narracja rozpoczyna się od opisu wydarzeń, które miały miejsce za panowania Juliana Apostaty, a kończy w roku 966. Ponieważ czasy Juliana Apostaty nie są w średniowiecznej tradycji historiograficznej okresem, od którego zwykło się rozpoczynać kroniki, niektórzy badacze ${ }^{4}$ są skłonni przypuszczać, że zaginiona część tekstu obejmuje okres wcześniejszy: od Narodzenia Pańskiego, a nawet od stworzenia świata. W tym wypadku mielibyśmy do czynienia z kroniką uniwersalną. Tezy tej jednak nie da się udowodnić na podstawie znanych nam obecnie źródeł. Równie

${ }^{2}$ BAV, Watykan, Chig.F.IV.75, 37v-38r.

${ }^{3}$ Fragmenty z Kroniki Benedykta znajdujemy w kronice Marcina Polaka, jednak P. Chiesa uznaje, że nie przedstawiają one większej wartości dla rekonstrukcji dzieła „Benedykta", gdyż po pierwsze nie są to dosłowne cytaty, a po drugie sam Marcin mógł mieć w ręku manuskrypt Chig.F.IV.75. Por. P. Chiesa, Benedictus Sancti Andreae de Soracte mon., [w:] „La trasmissione dei testi latini del medioevo - Medieval Latin Texts and their Transmission", I, Firenze - Impruneta 2004, s. 32, przyp.1.

${ }^{4}$ Np. A.-D. von den Brincken, Studien zur lateinischen Weltchronistik bis in das Zeitalter Ottos von Freising, Düsseldorf 1955, s. 139. 
trudne do udowodnienia, choć oparte na dość solidnych przesłankach byłoby przypuszczenie, iż Kronika z klasztoru na górze Soracte jest kroniką lokalną opisującą wydarzenia, które miały związek z tą fundacją, oraz umieszczającą je na tle historii ogólnej. Wskazywać by na to mogły częste wzmianki o Soracte w tekście Kroniki.

Trzeba przy okazji zaznaczyć, że tekst ten jest w dużej mierze kompilacją fragmentów innych dzieł historiograficznych. Należą do nich: Acta sanctae Bibianae, Vita sancti Martini Sulpicjusza Sewera, Vita sancti Barbati, Translatio corporis sancti Bartholomaei, Dialogi Grzegorza Wielkiego, Chronicon i De ratione temporum Bedy Czcigodnego, Historia Longobardorum Pawła Diakona, Annales regni Francorum, Vita Karoli Magni Einharda, oraz Libellus de imperatoria potestate. Wiemy zatem, że około roku 1000 mnisi z klasztoru św. Andrzeja na Soracte posiadali rękopisy tych dzieł. Co jednak ważniejsze, możemy mieć nadzieję, że dzięki dogłębnej analizie kompilacji (w czym bardzo pomocne mogą się okazać liczne błędy tekstu) dowiemy się więcej o postaci tych rękopisów. Nie możemy bowiem wykluczyć, że część niepoprawnych lekcji zawarta była w kodeksach służących za podstawę do kompilacji.

Kronika była wydawana dwukrotnie. Po raz pierwszy w serii Monumenta Germaniae Historica przez G. Pertza (SS III, Hannover 1839, s. 695-719). Po raz drugi przez G. Zuchettiego (Il Chronicon di Benedetto monaco di Sant' Andrea del Soratte, Rzym 1920). G. Pertz, przekonany, że Kronika jest autografem, napisanym przez niezbyt biegłego w łacinie mnicha, wydał ją w postaci fragmentarycznej. Te mianowicie części, które zostały przepisane $\mathrm{z}$ innych tekstów historiograficznych, pominąl, a pozostawił tylko to, co wydaje się pochodzić od samego Benedykta. Piszę „wydaje się", gdyż po prostu dziś nie jesteśmy w stanie wskazać innego pochodzenia tych fragmentów. To jednak nie dowodzi, że one również - a przynajmniej niektóre z nich - nie zostały skądś przepisane. Zagadkowa jest na przykład opowieść o wyprawie Karola Wielkiego na Bliski Wschód (karty 36 verso do 37 verso). Tę samą legendę odnajdujemy w sporo późniejszych tekstach łacińskich i francuskich. Jest jednak mało prawdopodobne, by Kronika Benedykta dostała się za Alpy. Świadczy o tym po pierwsze fakt, że do naszych czasów zachował się tylko jeden rękopis, a po drugie wyjątkowo zepsuta łacina, jaką napisany jest ten tekst. Dużo bardziej prawdopodobne jest, że autor Kroniki również w tym przypadku korzystał z jakiegoś źródła, z którego potem czerpali francuscy historiografowie. Wracając do wydania G. Pertza, trzeba zauważyć, że korzystanie zeń jest wyjątkowo niewygodne. Czytelnik nie ma 
bowiem do czynienia z tekstem ciągłym, a jedynie z urywkami, i jeśli chce je zebrać w jakąś całość, musi pozostałe fragmenty sam wyszukać.

G. Zuchetti dla odmiany postanowił wydać całość Kroniki. Potraktował jednak manuskrypt z ogromnym nabożeństwem. Postanowił niemal wcale nie ingerować $w$ tekst i dokonał w zasadzie transkrypcji raczej niż edycji. Poza interpunkcją i rozwiązaniami skrótów nie pozwolił sobie na żadną zmianę. Efektem jest tekst ciągły, ale w niewielkim stopniu czytelny. Niezależnie od tych decyzji wydawniczych Zuchetti poświęcił część wstępu do wydania na rozważanie kwestii transmisji tekstu. Uznał mianowicie rękopis z kodeksu Chig.F.IV.75 za kopię. Odrzucił tezę Pertza, jakoby chodziło o autograf, a na poparcie tego przedstawił zupełnie przekonujący argument. Zauważył mianowicie, że w cytowanym przez kompilatora wierszu przypisywanym papieżowi Damazemu znajduje się interpolowany wers „Quem impius apostata Iulianus destruxit” („który zburzył bezbożny apostata Julian"), który najprawdopodobniej był pierwotnie umieszczony na marginesie jako scholion, i odnosił się do wzmianki o kościele św. Sylwestra na Soracte. Ponieważ fragment, który poprzedza wiersz Damazego, nie jest - o ile nam wiadomo - przepisany skądinąd, ale wydaje się pochodzić od samego autora kompilacji, można jego interpolację do środka wiersza uznać za wystarczającą poszlakę za tym, że przed rękopisem z kodeksu Chig.F.IV.75 istniała wcześniejsza wersja Kroniki zawierająca marginalia, które następnie niedoświadczony kopista niesłusznie włączył do tekstu głównego. Tego rodzaju błędów jest zresztą więcej. Ostatecznie konkluzja Zuchettiego co do statusu naszego manuskryptu była taka, że nie jest on autografem, ale bardzo bliską kopią. Włoski badacz przypisał nawet poprawki, które występują w rękopisie, samemu Benedyktowi. To by jednak oznaczało, że autor kompilacji dość pobieżnie przeglądał tę kopię, większość bowiem błędów nie została poprawiona. By nie szukać dalej: marginalium niesłusznie inkorporowane do tekstu wiersza nie zostało zeń usunięte.

Po G. Zuchettim Kronika zainteresowało się niewielu badaczy. W roku 1961 J. Kunsemüller ${ }^{5}$ napisał w Norymberdze rozprawę poświęconą temu tekstowi. Nie została ona nigdy wydana. Jej maszynopis jest dostępny w bibliotece Uniwersytetu w Norymberdze. Kunsemüller przychylił się do opinii, że Kronika nie jest autografem. Dodatkowo wskazał w jej tekście wiele błędów, które z łatwością dają się wyjaśnić jako tak zwane „błędy ucha”, czyli powstałe przy pisaniu pod dyktando. W pracy

5 J. Kunsemüller, Die Chronik Benedikts von S. Andrea. Inaugural Dissertation der Philosophischen Fakultät der Friedrich Alexander Universität zu Erlangen, Nürnberg 1961. 
Kunsemüllera niezwykle ważne i cenne jest to, że jako pierwszy pokusił się o rozróżnienie poszczególnych rodzajów błędów. Podobnie jak Pertz i Zuchetti, Kunsemüller starał się odpowiedzieć na pytanie o status zachowanego tekstu Kroniki, oraz ustalić, jaki udział w jego powstawaniu mógł mieć sam Benedykt. Jego zdaniem autor mógł osobiście dyktować kopistom fragmenty kompilowanych dzieł. Jak jednak słusznie zauważył recenzent pracy Kunsemüllera, H. Hoffmann ${ }^{6}$, dowiedzenie, że niektóre błędy wskazują na pisanie pod dyktando, nie jest rozstrzygającym argumentem za tym, że tekst był dyktowany przez samego autora.

Dalsze badania nad Kronika, głównie paleograficzne i kodykologiczne, dały solidne przesłanki, by uznać, że nie tylko nie mamy do czynienia $\mathrm{z}$ autografem ani kopią autoryzowaną, ale raczej nawet nie z pierwszą kopią. P. Suppino-Martini ${ }^{7}$, w pracy poświęconej krojom pisma rozpowszechnionym w Lacjum, wspomina o manuskrypcie Chig.F.IV.75. i stwierdza, że dają się w nim wyróżnić trzy ręce (w tym dwie ręce w części kodeksu zawierającej Kronikę). P. Chiesa ${ }^{8}$ opublikował w roku 2004 artykuł, w którym przeanalizował rękopis od strony kodykologicznej. Obliczając dokładnie karty w zszywkach i biorąc pod uwagę naniesioną później paginację, dowodzi, że narracja Kroniki nie mogła sięgnąć dużo dalej niż rok 966. Benedykt musiał więc zaprzestać jej pisania około roku 970. Tymczasem analiza paleograficzna przesunęła czas powstania rękopisu z kodeksu Chig.F.IV.75 na lata dwudzieste XI wieku. To daje całe 50 lat między powstaniem autografu a powstaniem naszego manuskryptu. W ciągu tych 50 lat tekst mógł zostać skopiowany kilka razy. Liczba oraz rozmaitość błędów, które w nim napotykamy, zdają się sugerować, że kopii było więcej niż jedna.

Błędy te, choć niezmiernie utrudniają lekturę tekstu, mogą się jednak okazać cennym źródłem informacji w wielu dziedzinach. Językoznawcy, analizując tego rodzaju pomyłki, często opierają na nich swoje wnioski dotyczące ewolucji języka lacińskiego w wiekach średnich. Szczególnie cenne są zwłaszcza zabytki piśmiennictwa z czasów poprzedzających upowszechnienie ideałów reformy karolińskiej, która, wprowadzając określoną normę językową, przyczyniła się do swoistego „usztywnienia” jednego stanu języka i zapobiegła dalszej jego ewolucji. Dopóki jednak

6 „Deutsches Archiv für Erforschung des Mittelalters”, 20:1964, s. 596-597.

${ }^{7}$ P. Supino Martini, Roma e l'area grafica romanesca (secoli X-XII), Alessandria 1982, s. 291.

${ }^{8}$ Benedictus Sancti Andreae de Soracte mon., [w:] „La trasmissione dei testi latini del medioevo - Medieval Latin Texts and their Transmission”, I, Firenze - Impruneta 2004, s. 32-37. 
to nie nastąpiło (a zdaniem niektórych specjalistów do Lacjum w X wieku reforma jeszcze nie dotarła) mieszkańcy Italii posługiwali się językiem, który - prawdopodobnie - ich zdaniem był łaciną.

Są też jednak takie błędy, których nie należy składać na karb ewolucji językowej. Wynikają one z prostych mechanizmów pomyłek, jakie towarzyszą wszelkiemu kopiowaniu. Kopiści przepisując teksty średniowieczne podatni byli na dokładnie te same uchybienia, jak wtedy, gdy przepisywali dzieła autorów klasycznych. Problem polega na tym, że wydawca, mając do czynienia z twórczością Cycerona, może stwierdzić, że ten po prostu nie mógł napisać tak, jak czytamy w manuskrypcie. Dużo trudniej natomiast o taką dozę pewności, gdy pracuje sie z tekstem stworzonym w średniowieczu. Nie ulega bowiem wątpliwości, że niektóre formy, niedopuszczalne w starożytności, stały się powszechne w średniowieczu. Dlatego też ich odróżnienie od błędów kopiowania wymaga dużego wkładu pracy.

Żeby pokazać, jak różnorodne mogą być owe błędy, można posłużyć się takim oto zestawieniem ${ }^{9}$ i prześledzić różnice między Kronika a jej „źródłem”, czyli tekstem autorstwa Bedy Czcigodnego:

Gratianus cum fratre ${ }^{1}$ Valentiniano annos vi Theodosius augustus a Gratiano illas ${ }^{2}$ Sciticas gentes, hoc est Alanos, Hu$\operatorname{nos}^{3}$ et Gothos magnis multisque proeliis uincit. cuius concordiam ${ }^{4}$ non ferentes arriani praeter $\mathrm{xl}$ annos ecclesias, quas tenuerunt, relinquerunt. synodus cl patrum congregatur in urbe ${ }^{5}$ Augusta, aduersus Macedonum, sub Damaso Romae episcopo ${ }^{6}$. Theodosius Augustum Arcadium filium suum consortem ${ }^{7}$ fecit imperii.

qui multa in Italia arriana haeresis ${ }^{8}$ [Ambrosius episcopus Mediolano] et eminentissimam $^{9}$ catholicae fidei arcem $^{10}$ obsidione uexauit, qui prius quam prolatis beatorum Geruasii ${ }^{11}$ et Protasi ${ }^{12}$ martyrum deo reuelante ${ }^{13}$ reliquiis incorruptis $^{14}$ [sunt a] nefanda arriane facta deruit.
Gratianus cum fratre Valentiniano annis VI. Theodosius, a Gratiano imperator creatus, maximas illas Scythicas gentes, hoc est, Alanos, Hunos et Gothos magnis multisque praeliis vincit; cujus concordiam non ferentes Ariani, post $\underline{\mathrm{XL}}$ annos Ecclesias quas vi tenuere, reliquerunt. Synodus CL Patrum congregatur urbe Augusta adversus Macedonium sub Damaso Romae episcopo. Theodosius Arcadium filium suum consortem facit imperii. (...)

qui ${ }^{10}$ tamen justissimam cum matre sua Justina poenam luit exsilii, quia et ipsum Ariana polluit haeresis, et eminentissimam catholicae fidei arcem Ambrosium perfida obsidione vexavit, nec prius quam prolatis beatorum Gervasii et Protasii martyrum, Deo revelante, reliquiis incorruptis, nefanda coepta deseruit. (Beda, De ratione temporum, A.Chr 387, PL XC, col.)

${ }^{9} \mathrm{~W}$ poniższej tabeli przepisałam fragment Kroniki z karty 3 (koniec strony recto i początek verso). Zdecydowałam się zastosować grafię klasycyzującą, gdyż ta opcja edytorska wydaje mi się najlepsza z wielu powodów, których tu, z braku miejsca, nie wyłuszczę. Jed- 
Arcadius Augustus $\underline{\text { frater }}^{15}$ Theodosii cum fratre ${ }^{16}$ Honorio annos xiii.

Gothi in Italia ingressi sunt, qui prius Vandali atque Ilani, postmodum Gothi. Innocentius Romae episcopus eo tempore dedicauit basilicam Geruasii ${ }^{17}$ et Protasii $^{18}$ martyrum beatissimorum ex deuotione testamenti cuiusdam illustris feminae Vestinae ecclesiam composuit.
Arcadius filius Theodosii cum fratre Honorio annis XIII.

Gothi Italiam, Vandali atque Alani Gallias aggrediuntur. Innocentius, Romae episcopus, dedicavit basilicam Gervasii et Protasii martyrum beatissimorum, ex devotione testamenti cujusdam illustris feminae Vestinae ${ }^{11}$. (ibid. 411)

${ }^{1} \mathrm{~ms}$ : frater; ${ }^{2} \mathrm{~ms}$ : illa; ${ }^{3} \mathrm{~ms}$ : Unos; ${ }^{4} \mathrm{~ms}$ : concordia; ${ }^{5} \mathrm{~ms}$ : urbem ${ }^{6} \mathrm{~ms}$ : episcopus; ${ }^{7} \mathrm{~ms}$ : consorte; ${ }^{8} \mathrm{~ms}$ : haereses; ${ }^{9} \mathrm{~ms}$ : eminentissimus; ${ }^{10} \mathrm{~ms}$ : arce; ${ }^{11} \mathrm{~ms}$ : gerbasi $\mathrm{cum}$, , ${ }^{\prime}$ secunda manu superscriptum; ${ }^{12} \mathrm{~ms}$ : protasi; ${ }^{13} \mathrm{~ms}$ : reuelantem; ${ }^{14} \mathrm{~ms}$ : incorrupti; ${ }^{15} \mathrm{~ms}$ : fratres; ${ }^{16} \mathrm{~ms}$ : fratres; ${ }^{17} \mathrm{~ms}$ : gerbasi; ${ }^{18} \mathrm{~ms}$ : protasi;

Część błędnych lekcji rękopisu daje się bardzo łatwo wyjaśnić wymową. Zwłaszcza, gdy kopiowanie polegało na dyktowaniu tekstu, skryba mógł mieć dużą skłonność do niezapisywania dźwięków, których nie słyszał, lub - wskutek hiperpoprawności - zapisywania ich tam, gdzie ich być nie powinno. Najpopularniejsze wśród tych błędów ortograficznych jest pomijanie wygłosowego -m w formach accusativu singularis, albo wręcz odwrotnie - dopisywanie go w fomach ablativu singularis. Wygłosowe -m było niesłyszalne już w starożytności, o czym najlepiej świadczą zasady klasycznej metryki. Kopista, który uczył się pisać po łacinie, wiedział, że formy accusativu i ablativu różnią się graficznie, mimo iż czyta się je tak samo. Jednak przez nieuwagę, zwłaszcza, gdy pisał pod czyjeś dyktando, mógł się mylić i robić błędy ortograficzne. Im słabiej był wy-

nym z nich, i nie najmniej ważnym, jest fakt, że w ten sposób ułatwiamy odbiór czytelnikowi, który może bez dodatkowych utrudnień korzystać przy tłumaczeniu ze słowników i gramatyk, a one zawsze posługują się grafią klasyczną.

${ }^{10}$ Mowa o Walentynianie.

11 Gracjan z bratem Walentynianem lat 6. Teodozjusz mianowany cesarzem przez Gracjana, zwyciężył w wielkich i licznych bojach owe wielkie scytyjskie ludy, to jest Alanów, Hunów i Gotów. Którego zgody nie mogąc znieść, arianie po 40 latach opuścili kościoły, które siłą trzymali. Synod stu pięćdziesięciu ojców zbiera się w mieście cesarskim przeciw Macedoniuszowi, pod przewodnictwem Damazego, biskupa Rzymu. Teodozjusz mianuje swego syna Arkadiusza współcesarzem. (...) Który jednak z matką swą Justyną najsprawiedliwszą karę wygnania poniósł, gdyż i jego samego splamiła herezja ariańska, i Ambrożego, największą twierdzę katolickiej wiary nękał perfidnym oblężeniem i nie wcześniej odstąpił od niegodnych machinacji, jak dopiero gdy, za Bożym wskazaniem, odkryte zostaly relikwie świętych Gerwazego i Protazego, zupełnie nietknięte. (...) Arkadiusz, syn Teodozjusza, z bratem Honoriuszem trzynaście lat. Goci Italię, Wandalowie i Alanowie Galię zajmują. Innocenty, biskup Rzymu, poświęcił bazylikę Gerwazego i Protazego, świętych męczenników, zgodnie z testamentem pewnej znamienitej niewiasty, Westiny" - tłum. B.S. 
kształcony w pisaniu i łacinie (co właściwie sprowadza się do jednego, gdyż nauka pisania w $\mathrm{X}$ wieku oznaczała naukę pisania po łacinie), tym więcej popełniał takich błędów. Do wydawcy należy poprawienie ich, co też zrobiłam w powyższej tabelce, zaznaczając w aparacie krytycznym lekcję rękopisu. Mamy bowiem: „concordia” zamiast „concordiam”, „urbem” zamiast „urbe”, „consorte” zamiast „,consortem”, „arce” zamiast „arcem”, „reuelantem” zamiast „reuelante”. Dokładnie tak samo przedstawia się sytuacja z nagłosowym „h”. Nie było ono słyszalne już w późnej starożytności. Dlatego też kopista z łatwością może się pomylić i napisać „Unos” zamiast „Hunos”. W innych miejscach znajdujemy formę „hurbs” zamiast „urbs”. Są to błędy dokładnie tego samego rodzaju, co te, do których miewają skłonność użytkownicy języka polskiego, pisząc „rzaba” zamiast „żaba”. Z pewnością łatwiej je popełnić, gdy pisze się ze słuchu, ale mogą się też one zdarzyć przy kopiowaniu wzrokowym. To samo dotyczy zapisania „haereses” zamiast „haeresis”. Wiadomo bowiem skądinąd, że w późnej łacinie końcówki -is i -es czytały się tak samo.

Nieco innym błędem, choć również łatwym do popełnienia jest napisanie ,illa Scyticas” zamiast „illas Scyticas”. Dwie głoski „s”, jedna w wygłosie, druga w nagłosie, mogą z łatwością być usłyszane jako jeden dźwięk i tak zapisane.

To jednak nie wyczerpuje wszystkich odmiennych lekcji rękopisu z kodeksu Chig.F.IV.75. Porównując jego tekst z fragmentem dzieła Bedy Czcigodnego, możemy zaobserwować pewne zmiany. Różniące się miejsca zaznaczyłam w tabelce podkreślając odpowiednie słowa. Oto ich omówienie:

1) Kopista, przepisując tekst Bedy, opuścił dwa słowa: „creatus” i „maximas". O ile opuszczenie tego drugiego nie zaburza struktury zdania, o tyle nie da się tego samego powiedzieć o pierwszym z nich. Opuszczenie tego rodzaju łatwo może przytrafić się kopiście, sugeruje jednak co najmniej nieuwagę przy przepisywaniu, jeśli nie wręcz słabe zrozumienie kopiowanego tekstu.

2) Zamiast „post xl annos” kopista napisał „praeter xl annos”. Wynikać to może ze złego odczytania skrótu, ale, podobnie jak błąd poprzedni, sugeruje albo nieuwagę albo słabe zrozumienie przepisywanego zdania. To samo można powiedzieć o użyciu „frater” zamiast „fratre” oraz o dwukrotnym użyciu „fratres” zamiast „frater”. Te ostatnie zresztą zapisane są w Chig.F.IV.75 skrótem.

3) Z dłuższego passusu u Bedy, w którym opisano pokrótce działania Walentyniana, kopista zachował tylko „qui”, opuszczając zdanie, do 
którego odnosi się zaimek, oraz część, która po zaimku bezpośrednio występuje. Gdyby pominąć niepasujące do niczego „qui”, zdanie jednak miałoby sens, nawet przy braku orzeczenia „polluit” do „haeresis”. Mielibyśmy wówczas zdanie: „multa in Italia arriana haeresis et eminentissimam fidei catholicae arcem obsidione uexauit” - ,ariańska herezja gnębiła oblężeniem wiele (miejsc) w Italii, a także najwybitniejszą twierdzę katolickiej wiary". W tym celu jednak trzeba uznać słowa „Ambrosius episcopus Mediolano” za marginalium, które przy tworzeniu kolejnej kopii dostało się do tekstu. Tego rodzaju pomyłek mamy w Kronice kilka. Pytanie tylko, czy marginalium to znajdowało się we wcześniejszej kopii kroniki, czy w posiadanym przez skryptorium klasztoru św. Andrzeja rękopisie Bedy. Pierwsze rozwiązanie wydaje się sensowniejsze. Zakłada bowiem istnienie starszej i lepszej kopii Kroniki, co zdaje się potwierdzać przeróbka, jakiej dokonano na tekście Bedy. Autor byłby wówczas odpowiedzialny za rozsądne kompilowanie, wymagające dobrego rozumienia czytanych dzieł. Dopiero późniejsi kopiści, nie rozumiejąc dokładnie przepisywanego tekstu, wpletliby doń marginalia.

Jest jednak jeszcze inna ewentualność. Możemy poprawić „multa in Italia arriana haeresis Ambrosius episcopus Mediolano et eminentissimam catholicae fidei arcem obsidione uexauit" na „multos in Italia arriana haeresis et eminentissimam catholicae fidei arcem, Ambrosium episcopum Mediolani, obsidione uexauit". Wymaga to chyba jednak większych poprawek.

4) Trudniej wyjaśnić zmianę z „nec” na „qui”. Nie dość, że nie jest to ewidentny błąd ucha ani oka, to na dodatek lekcja ta psuje wyraźnie sens zdania. Podobnie jak zmiana z ,incorruptis” na ,incorrupti sunt a”.

5) Natomiast zmiana $z$ „coepta” na „facta” bez problemu wyjaśnia się złym odczytaniem tekstu Bedy. Podobnie jak synkopa, która zaszła w „deseruit”, dając „deruit”. Oba błędy należy zaliczyć do błędów oka.

6) Zmiana z „filius” na „frater” wyjaśnia się najprościej złym odczytaniem skrótu.

10) Dużo większa zmiana zachodzi w zdaniu „Gothi Italiam, Vandali atque Alani Gallias aggrediuntur.” Wydaje się, że autor Kroniki celowo zmienił je na „Gothi in Italia ingressi sunt, qui prius Vandali atque Ilani, postmodum Gothi." Choć składnia jest tu zdecydowanie nieklasyczna (zaskakuje zwłaszcza zaimek „qui”), a sens zdania różny od Bedowego, zdaje się ono jednak dość dobrze bronić. Jeśli uznać je za autorską wersję Benedykta, to mielibyśmy tu do czynie- 
nia $\mathrm{z}$ fragmentem autentycznej łaciny, jaką posługiwano się w Italii $\mathrm{X}$ wieku.

Ten krótki przegląd ma na celu wykazanie, jak rozmaite są błędy zawarte w Kronice. Ich dogłębna analiza i klasyfikacja jest niezbędna. Pozwoli ona bowiem najpierw oczyścić tekst z prostych błędów ortograficznych, które co prawda dla językoznawców przedstawiają pewną wartość, ale jednocześnie utrudniają innym czytelnikom jego zrozumienie. Dlatego też, wbrew niektórym modom wydawniczym, postanowiłam od razu wprowadzić te proste poprawki do głównego tekstu. Miało to na celu przede wszystkim wyraźne oddzielenie różnych kategorii błędów. Dopiero po takim wstępnym wydzieleniu możemy dokładniej przebadać inne ciekawostki językowe, w jakie obfituje Kronika. Te ostatnie, mniej interesujące dla językoznawców, mogą jednak zaciekawić tych, którzy zajmują się transmisją tekstu i historią skryptoriów. Dla nich Kronika Benedykta jest $\mathrm{z}$ pewnością bardzo wartościowym źródłem. Wynika to ze specyfiki tego tekstu, który - przypomnijmy - jest kompilacją fragmentów zaczerpniętych $\mathrm{z}$ dzieł historio- i hagiograficznych. Porównanie ich z fragmentami źródeł, z których korzystał kompilator, może wzbogacić naszą wiedzę o tradycji rękopiśmiennej tychże źródeł, gdyż niektóre lekcje rękopisu mogą pochodzić z lekcji zawartych w manuskryptach będących w posiadaniu skryptorium klasztoru św. Andrzeja na górze Soracte.

W komentarzu do powyższego zestawienia zwróciłam uwagę na kilka wątpliwych miejsc, zaznaczając, że niektóre lekcje mogły znajdować się już w dostępnej Benedyktowi kopii dzieła Bedy. Z pewnością wiele takich wątpliwości będzie łatwiej rozstrzygnąć, jeśli zaznajomimy się bliżej $\mathrm{z}$ tradycją rękopiśmienną De ratione temporum. Występowanie takich a nie innych błędów w Kronice pomoże nam ją przypisać, jeśli nie do konkretnego rękopisu, to przynajmniej do jednej rodziny kodeksów. To z kolei może dostarczyć dodatkowych informacji o tejże rodzinie. Tego rodzaju wnikliwe analizowanie poszczególnych lekcji manuskryptów ma szanse okazać się bardzo pomocne dla każdego, kto interesuje się nie tylko samą transmisją tekstów, ale również historią skryptoriów, zasięgiem geograficznym różnych dzieł i w ogóle kontaktami intelektualnymi w średniowiecznej Europie.

Pewne podstawy pod taką pracę położył już G. Zuchetti w przypisach do swojego wydania. Zauważył on mianowicie, że niektóre lekcje znajdujących się w Kronice fragmentów z Acta sanctae Bibianae zgodne są $\mathrm{z}$ jedną tylko częścią tradycji rękopiśmiennej tego hagiograficznego tekstu. Na stronie 4 (n.1) zauważa, że Benedykt najwyraźniej miał do czy- 
nienia z redakcją Akt podobną do tej, którą zachowały kodeksy Vat. lat. 5696 i kodeks I z archiwum Santa Maria Maggiore w Rzymie. Dokładniejsza analiza tych podobieństw jest zatem konieczna, jeśli chcemy dowiedzieć się więcej o sposobie konstruowania Kroniki oraz o transmisji tego tekstu. Ale może ona też rzucić nowe światło na historię transmisji i rozpowszechnienia $A k t$.

Również bardzo ciekawe pole do poszukiwań oferuje nam inny ważny tekst, a mianowicie Vita sancti Barbati. Jest to niedługie dziełko hagiograficzne poświęcone św. Barbatusowi, biskupowi Benewentu. Powstało ono z pewnością po napisaniu przez Pawła Diakona Historii Longobardów, a przed skompilowaniem naszej Kroniki. Zachowało się w dwunastu rękopisach i stanowi ważne źródło dla historyków i religioznawców, gdyż opowiada między innymi o pewnych rytuałach pogańskich Longobardów. Zostało ono wydane w kolekcji $M G H$ przez G. Wait$\mathrm{za}^{12}$. Najstarszym manuskryptem zawierającym ten tekst jest właśnie Kronika Benedykta. Waitz zaznacza, że w tym rękopisie Vita Barbati jest „wolna od interpolacji”, podobnie jak w rękopisie opatrzonym przezeń numerem 1. (Romanus Vallicellianus IV). Tekst w obu tych źródłach napisany jest „niedbale i wieloma błędami splamiony”. Waitz, podkreślając, że wersję z Chig.F.IV.75 spisał „scriptor barbarus”, który „nieco od siebie dodał", przyznaje, że jako najstarszy, rękopis ten pomaga niekiedy odtworzyć pierwotną wersję tekstu.

Benedykt, włączając żywot Barbatusa do swej Kroniki, uznał za stosowne zrezygnować z prologu, co sprawia, że historia świętego biskupa Benewentu lepiej łączy się z narracją, która ją poprzedza. Jednak i w tym miejscu nieuwaga kompilatora dała ciekawy efekt. W pierwszym bowiem akapicie autor żywotu nawiązując do tego, co wzmiankował w prologu, pisze: „insignis sacerdos Barbatus nomine, ut fatus sum, Redemptoris nutu claruit Beneventi” (,znamienity kapłan, imieniem Barbatus, jak powiedziałem, za natchnieniem Zbawiciela, słynął w Benewencie”). Autor Kroniki natomiast, zrezygnowawszy z prologu, pisze na karcie 11 recto: „Grimualdus rex successit in regno. Langobardorum regni moderabat habenas. Eiusque filius Romuald Samnitibus imperabat. Insignis sacerdos Barbatus nomine, ut praefatus sum, Redemptoris nutu claruit Beneventi” („Król Grimoald odziedziczył panowanie i trzymał stery królestwa Longobardów. A jego syn, Romuald rządził Samnitami. Znamienity kapłan, imieniem Barbatus, jak powiedziałem, za natchnieniem

12 Vita Barbati episcopi Beneventani, ed. G. Waitz, MGH, Scriptores Rerum Longobardicarum, Hannoverae 1878, s. 555-563. 
Zbawiciela słynął w Benewencie”). Zachowanie zdania ,jak powiedziałem" nie ma oczywiście najmniejszego sensu w tekście Kroniki.

Porównując poszczególne wersje Vita Barbati, zauważamy, że ta, którą kompilator inkorporował do swej Kroniki, ma najwięcej cech wspólnych z wersjami zawartymi w kodeksach Romanus Vallicellianus IV oraz Romanus Vallicellianus $I X$. Żaden z trzech tekstów nie jest źródłem dwóch innych, najwyraźniej jednak pochodzą z tej samej rodziny rękopisów. Bardziej szczegółowe ich porównanie może dostarczyć wielu cennych informacji nie tylko o tradycji rękopiśmiennej Kroniki, ale również o tradycji rękopiśmiennej Vita Barbati, podobnie jak i innych tekstów stanowiących podstawę kompilacji

Podsumowując, niezależnie od wartości historiograficznej i źródłoznawczej tego interesującego tekstu, jakim jest Kronika Benedykta z Soracte, możemy mieć nadzieję, że dokładniejsza jego analiza okaże się cenna również w innych dziedzinach.

\section{Summary}

\section{On Medieval Compiling and Text Transmission: The Instance of the Chronicle of Benedict from the Monastery of St. Andrew's on Mount Soracte}

The Chronicle written during the waning years of the $10^{\text {th }}$ century by Benedict, monk of St. Andrew's Monastery on Mount Soracte, is a most interesting example of a compilatory historiographical texts. Among other this Chronicle is full of linguistic forms which, according the norms of classical or even medieval Latin, should be considered erroneous. Nevertheless, this feature which at first may cause problems for the reader, seems to offer research perspectives as yet not explored with this author. At least some of these "errors" are rather recordings of changes in the language, which are most important for diachronic linguistics. Moreover, the "regular" errors committed by the scribe during the process of copying fragments of other sources, can also enlarge our knowledge of medieval scriptoria and the transmission of texts. However, before the stage of drawing conclusions concerning these wider aspects of the medieval culture can be reached, the task of analysing and categorising all grammatical forms, which do not conform with the standard, must be performed first. 